EMPOWER : Jurnal Pengembangan Masyarakat Islam

Vol. 5, No.1, Juni 2020, hlm. 174-190

e-ISSN : 2580-0973, p-ISSN : 2580-085X

Tersedia Online di : http://syekhnurjati.ac.id/jurnal/index.php/empower

Email : empowerjurnal@gmail.com

\title{
Politik Etnosentris Semu Dalam Kasus Upaya Pemekaran Provinsi (Studi Pada Gerakan Pemekaran Provinsi Cirebon)
}

\author{
Ficky Utomo* \\ (Program Studi Ilmu Politik, Fakultas Ilmu Hukum, Universitas Indonesia ) \\ Email: fickydoank55@gmail.com, \\ Julian Aldrin Pasha** \\ (Program Studi Ilmu Politik, Fakultas Ilmu Hukum, Universitas Indonesia) \\ Email: fickydoank55@gmail.com
}

\section{Article History}

Submitted: 07.12.2020; Revised: 14.06.2020; Accepted: 21.06.2020;

\begin{abstract}
This study discusses about the ethnocentric based political movements that are false (pseudo- ethnocentric politics) in the case of deadlock effort for Cirebon Provinces segregation. This study uses the theory of governability, Theory of Social Movements, Theory of ethnocentrism, and the Theory of Rent-Seeking in dissecting the issue of the proposed research regarding the causes of ontological substance of the Cirebon Province segregation movement, how the movement of the expansion is done, the goal of some parties spreading issues about ethnocentric in the period of Cirebon Province divergence movement, and finally as a tool for analysis to uncover the reasons substantially deadlock Keraton Cirebon Elit effort with the P3C Organization in Cirebon and its Provinces movement determinant implications after the deadlock occurred. By using qualitative methods of the literature and collected data through in-depth interviews. Researchers have argued that the conditions of management of the West Java Provincial Government in the category of un-governability was the cause of the ontological substance of Cirebon Province segregation movement. That the derivation is the rise of forms of movement by the elites and activists Provinces Cirebon. The researchers also found, the issue of
\end{abstract}


ethnocentrism used as a propaganda tool in order to strengthen the solidity of the group. And the reason for the deadlock substantive motion Cirebon Provinces is more to the practice of rent-seeking among the position holders involved (central and regional). In this study were also presented regarding the emergence of the idea for transfer the Capitalcity to Cirebon and Majalengka and the movement for divergence the district of Indramayu and Cirebon as a result of the deadlock implikatif (discontinuities) of Cirebon Province segregation movement.

Keywords: Pseudo-Ethnocentric Politics, Cirebon Province Expansion, Cirebon Palace Elite, P3C.

\begin{abstract}
Abstrak
Penelitian ini membahas mengenai gerakan politik berbasis etnosentris yang sifatnya semu (pseudo-politik etnosentris) di dalam kasus kebuntuan usaha pemekaran Provinsi Cirebon. Penelitian ini menggunakan Teori Governability, Teori Gerakan Sosial, Teori Etnosentrisme, dan Teori Rent-Seeking di dalam membedah persoalan penelitian yang diajukan perihal sebab ontologis lahirnya gerakan pemekaran Provinsi Cirebon, bagaimana gerakan pemekaran itu dilakukan, tujuan beberapa pihak mempergulirkan isu etnosentris di dalam masa pengupayaan pemekaran Provinsi Cirebon, dan terakhir sebagai pisau analisis untuk menguak alasan substansial atas kebuntuan usaha Elit Keraton Cirebon bersama Organisasi Presidium Pembentukan Provinsi Cirebon di dalam gerakan pemekaran Provinsi Cirebon beserta implikasi determinan setelah kebuntuan tersebut terjadi. Dengan menggunakan metode kualitatif yaitu dengan studi pustaka dan mengumpulkan data melalui wawancara mendalam. Peneliti beragumen bahwa kondisi kepengurusan Pemerintah Provinsi Jawa Barat yang masuk dalam kategori un-governability menjadi sebab ontologis atas lahirnya gerakan pemekaran Provinsi Cirebon. Yang derivatnya adalah lahirnya bentuk-bentuk gerakan yang dilakukan oleh para elit dan aktivis gerakan pemekaran Provinsi Cirebon. Peneliti juga berpendapat bahwa, isu etnosentrisme dijadikan alat propaganda dalam rangka memperkuat soliditas kelompok. Dan alasan substantif dalam kebuntuan gerakan pemekaran Provinsi Cirebon ini lebih kepada terjadinya praktik
\end{abstract}


rent-seeking dikalangan pemangku jabatan terkait (baik pusat maupun daerah). Di dalam penelitian ini juga dipaparkan perihal munculnya gagasan pemindahan Ibukota Provinsi ke Cirebon atau Majalengka serta terjadinya divergensi wilayah Kabupaten Indramayu dan Kabupaten Cirebon sebagai dampak implikatif dari kebuntuan (diskontinuitas) gerakan pemekaran Provinsi Cirebon.

Kata Kunci: Politik Etnosentris Semu, Pemekaran Provinsi Cirebon, Elit Keraton, P3C.

\section{PENDAHULUAN}

Selama 32 tahun Indonesia terkekang dalam otoritarianisme Orde Baru, tidak hanya itu, bahkan Indonesia sangat tersentralisir begitu rupa. Wajar bila pasca fase kesejarahan rezim Orde Baru dilewati, kerinduan akan rasa kemandirian pada masing-masing daerah kembali mencuat. Banyak dari daerah di Indonesia kemudian satu persatu mekar menjadi kabupaten, kota, ataupun provinsi baru. Hal tersebut tidak lepas bahwa otonomi daerah adalah manifestasi dari desentralisasi dan dalam kaitannya dapat kita bagi menjadi empat tipe, yakni desentralisasi, yaitu; deconcentration, delegation, devolution, and privatization, menurut Mathur1, power yang terdistribusi dan tidak tersentralisir diharapkan bisa membawa angin kesegaran bagi pembangunan wilayah-wilayah otonom yang ada di Indonesia. Spirit pembangunan berbasis lokal tersebut mencuat ketika pemerintahan Soeharto yang berkuasa selama kurang lebihnya 32 tahun termakzulkan dengan peristiwa reformasi yang dilakukan oleh masyarakat dan mahasiwa. Hal ini mendeterminasikan perubahan struktur budaya pemerintahan yang sebelumnya, yakni pada masa orde baru sedemikian sentralistis, bertransformasi atau bergeser menuju pemerintahan yang desentralistis yang mana kekuasaan dan kewenangan mengenai pemerintahan daerah dilimpah-tugaskan pada daerahnya masing-masing (pembangunan berdasarkan lokalitas) dan dikuatkan dengan adanya sumber hukum yaitu UU No. 22 Tahun 1999 dan direvisi menjadi UU No.

1 Reynold Simandjuntak, Sistem Desentralisasi Dalam Negara Kesatuan Republik Indonesia Perspektif Yuridis Konstitusional (Manado: UGM, 2015), p. 61. 
32 Tahun 2004 yang di dalamnya menjabarkan perihal relasi struktur hierarki antara Kabupaten dengan Provinsi, antara Provinsi dengan Pemerintah Pusat. Kewenangan dan kekuasaan yang didistribusikan oleh pemerintah pusat kepada pemerintah daerah dengan prinsip desentralisasi, dimana pemerintah pusat memberikan kewenangan atau keleluasaan bagi pemerintah daerah untuk membangun dan mengatur rumah tangganya sendiri².

Hasil dari hal ini ternyata mendeterminasikan implikasi yang sedemikian kuat kepada daerah yang memiliki sumberdaya alam atau pendapatan daerah yang tinggi dibandingkan wilayah lain untuk melakukan pembangunan dan pemugaran daerahnya secara ekonomi, sosial, budaya, pendidikan, dan lain sebagainya. Selain dari pada sumberdaya alam, beberapa poin alasan mengapa sebuah daerah berinisiasi untuk melakukan pemekaran daerah antara lain spirit untuk mempergelarkan pemerataan dan keadilan ekonomi, lokus wilayah geografis yang terlampau luas, perbedaan basis identitas (inter-komunal), kegagalan pengelolaan konflik interkomunal, setelahnya masuk ke dalam poin prasyarat inisiasi pemekaran, di dalam PP No. 129 tahun 2000, pemekaran daerah dan atau konvergensi kewilayahan daerah dan RPP tentang tata cara pembentukan, penghapusan dan penggabungan daerah tahun 2006 ditegaskan bahwa proses inisiasi pemekaran daerah tergantung pada kuatnya dukungan dan inisiatif daerah ${ }^{3}$. Hal tersebut dapat kita baca secara sangat jelas ketika kita melihat alur proses inisiasi pemekaran daerah pada pasal 16 dan 17 dalam PP. 129 Tahun 2000.

Dinamika menyoal proses inisiasi otonomi daerah mulai mencuat kembali pasca tergulingkannya rezim orde baru yang memberikan implikasi cukup signifikan mengenai banyaknya keinginan wilayahwilayah baru untuk mengurus lokus kewilayahannya sendiri. Tri Ratnawati mengatakan, ada 4 (empat) faktor pendorong tingginya spirit masyakarat dan elit-elit daerah untuk melakukan pemekaran wilayah, yakni : 1.) efektivitas/efisiensi dan dekadensi pembangunan; 2.) kecenderungan

\footnotetext{
2 Hanif, Hasrul, and Pratikno, Perjuangan Menuju Puncak (Yogyakarta: Program Pascasarjana (S2) Politik Lokal dan Otonomi Daerah UGM, 2006), p. 3.

${ }^{3}$ Hanif, Hasrul, and Pratikno, p. 2.
} 
homogeniasasi daerah berdasarkan agama, etnis, bahasa, dll; 3.) munculnya kemanjaan fiskal yang dijamin oleh UU bagi daerah yang dimekarkan seperti adanya DAU, bagi hasil dari SDA, PAD dll; 4.) bureaucratic and political rent-seeking yaitu motif elit-elit politik tertentu untuk memburu rente atau mengejar keuntungan ekonomi dan politis melalui pemekaran daerah baru4 .

Hal serupa ini-lah yang terjadi di wilayah Provinsi Jawa Barat. Isu perihal keinginan Cirebon memisahkan diri dari Jawa Barat sebenarnya sudah lama muncul, keinginan tersebut tidak terlepas dari beberapa permasalahan, seperti masalah kebudayaan atau kebahasaan (masalahmasalah bersifat primordial) yang faktanya sedari dahulu sampai dengan saat ini, Cirebon adalah salah satu wilayah yang tidak menggunakan bahasa Sunda (hal serupa pula terjadi di Indramayu), dalam fragmen kesejarahan di Provinsi Jawa Barat, konflik mengenai Cirebon dengan Jawa Barat sebenarnya telah muncul sejak tahun 1948, konflik tersebut dilatarbelakangi pertarungan elit di masa lalu, ketika tokoh-tokoh Cirebon menghadiri sidang konferensi Jawa Jarat III di Bandung pada tanggal 28 Februari tahun 1948, para tokoh Cirebon menolak statement salah satu tokoh Jawa Barat (baca : Sunda) yaitu Soeria Kartalegawa mengenai pemberlakuan bahasa siding (bahasa Pasundan atau Sunda) di wilayah Jawa bagian barat. Konflik partikular yang terjadi sekian lama antara kelompok elit Pasundan dengan kelompok elit Cirebon sebenarnya muncul sejak Indonesia baru berumur 3 tahun (bahkan semenjak zaman Walisongo sudah muncul embrio konflik antar kelompok primordial tersebut), konflik tersebut sebenarnya dimulai dari elit-elit atau tokoh-tokoh politik daerah yang ada di kedua wilayah tersebut.

Spirit wilayah tiga Cirebon untuk memisahkan diri dari Jawa Barat kembali muncul ketika adanya Undang-Undang No. 23 Tahun 2000 perihal pengesahan wilayah Banten Raya sebagai provinsi baru yang otonom dan keluar dari wilayah administratif Jawa Barat. Keberhasilan mekarnya Provinsi Banten tidak lepas dari peran serta masyarakat dan peran elit lokal di Provinsi tersebut. Pada tahun 1999, masyarakat Banten melakukan deklarasi di alun-alun Kota Banten guna menginkan pembentukan Provinsi

\footnotetext{
4 Tri Ratnawati, Potret Pemerintahan Lokal Di Indonesia Di Masa Perubahan (Jakarta: Pustaka Pelajar, 2006), p. 110.
} 
Banten ${ }^{5}$, pemekaran wilayah tersebut mendeterminasikan kembali bergairahnya sebagian wilayah di Jawa Barat yang ingin memisahkan diri seperti Bogor yang berkeinginan untuk memisahkan diri dengan Jawa Barat dan membentuk Provinsi Bogor Raya.

Menilik dari perjuangan empiris Banten dalam keberhasilannya memperjuangkan pemekaran provinsi, di wilayah Cirebon saat ini (tahun 2018) mulai menguat kembali isu pemekaran yang sudah redup dari awal tahun 1950-an tersebut, menguatnya isu tersebut dilatar belakangi oleh munculnya sebuah gerakan politik yang terjadi di Wilayah Cirebon (Kota dan Kabupaten), Indramayu, Majalengka dan Kuningan, yakni Presidium Pembentukan Provinsi Cirebon (P3C) yang dibentuk oleh "masyarakat" dan juga elit pemerintah dan keraton-keraton se-Cirebon yang dalam beberapa tahun ini dinilai sangat vokal dalam menyerukan pembentukan Provinsi baru Cirebon. Hingga saat ini ada dua alasan yang selalu disuarakan untuk memisahkan diri dari Provinsi Jawa Barat oleh gerakan tersebut yaitu masalah sejarah (dimensi historis kebudayaan) dan masalah ekonomi.

Hal tersebut diperkuat ketika isu pembentukan Provinsi Cirebon meliputi wilayah-wilayah yang saat ini menjadi dinamisator pembangkit ekonomi di Jawa Barat yaitu Kabupaten Cirebon, Kabupaten Kuningan, Kabupaten Majalengka, dan Kabupaten Indramayu (Ci-Ayu-Maja-Kuning). Menurut peneliti yang juga sebagai masyarakat Jawa Barat, ke lima wilayah tersebut sudah memiliki spesialisasi masing-masing dimana kekuatan industri dan jasa dipegang oleh wilayah Cirebon, kekuatan perikanan, pertanian dipegang oleh wilayah Indramayu, kekuatan dilevel pariwisata dan agronomi dipegang oleh Kabupaten Kuningan dan terakhir wilayah spesialisasi agronomi dan perkebunan yaitu wilayah Majalengka.

Maka dari uraian diatas, inisiasi pemekaran di wilayah Ciayumajakuning tidak terlepas dari adanya beberapa aktor politik yang ada di wilayah tersebut seperti elit birokrasi daerah, masyarakat, dan kekuatan lokal "Keraton-Keraton se Kota Cirebon" yang terlihat ketika

\footnotetext{
5 Humas Protokol Banten, 'Profil Provinsi Banten' <http://www.humasprotokol.bantenprov.go.id/2012/07/profil-provinsi-banten/> [accessed 9 December 2018].
} 
acara halal bihalal paguyuban sedulur Cirebon ${ }^{6}$, tokoh-tokoh sentral dari beberapa kabupaten yang mendukung dan menandatangani terbentuknya Provinsi Cirebon, walaupun disatu sisi Gubernur Jawa Barat tidak menyepakati terbentuknya Provinsi tersebut, selain itu beberapa elemen masyarakat yang berada di beberapa daerah di wilayah tersebut menolak terbentuknya sebuah pemekaran wilayah.

Maraknya beberapa wilayah yang ingin memisahkan diri dari wilayah sebelumnya, bisa dikatakan sebagai hasil determinasi implikatif dari kemudahan pra-syarat pembentukan sebuah wilayah otonom baru dan didorong oleh beberapa Undang-Undang dan juga peraturan pemerintah yang dinilai terlampau memudahkan beberapa daerah untuk memisahkan diri, dari beberapa syarakat kemudahan yang diberikan oleh pemerintah pusat tersebut dijadikan sebuah kesempatan oleh beberapa aktor perubahan untuk mengorganisir dan membentuk sebuah gerakan untuk menuntut sebuah pemekaran daerah. Namun dalam prosesnya, pengupayaan pembentukan provinsi baru ini mendapatkan banyak kendala dan konflik internal antar daerah (Ciayumajakuning) yang dirangkul untuk menjadi satu kesatuan provinsi baru, elit keraton Cirebon beserta para aktivis P3C seperti mendapatkan kebuntuan gerakan, belum lagi upaya Pemerintah Provinsi Jawa Barat yang berniat akan menjadikan Cirebon atau Majalengka menjadi Ibukota baru bagi Provinsi Jawa Barat. Hal ini seperti sengaja dibuat oleh Pemerintah Jawa Barat dalam rangka mengalihkan perhatian masyarakat Wilayah Tiga Cirebon (kalau tidak bisa disebut menghalangi pemekaran). Maka hal-hal ini-lah yang akan menjadi garis besar penelitian yang akan peneliti buat di dalam bentuk jurnal ini. Penelitian perihal masalah diskontinuitas (ketidakberlanjutan/kebuntuan) gerakan pemekaran Provinsi Cirebon ini, peneliti berikan judul, "Politik Etnosentris Semu Dalam Kasus Upaya Pemekaran Provinsi (Studi Pada Gerakan Pemekaran Provinsi Cirebon)".

Jenis penelitian yang digunakan adalah kualitatif deskriptif, penelitian ini dilakukan di Cirebon (Sekretariat P3C) dan Keraton-Keraton

6 Radar Cirebon, 'Gerakan Pemekaran Provinsi Cirebon Diabaikan', 2018 <http://radarcirebon.com/2010/09/berita-nasional/provinsi-cirebon-diabaikan/> [accessed 7 December 2018]. 
Se-Cirebon, data yang dikumpulkan berupa data hasil wawancara dari beberapa pihak yang terkait. Diantara pihak-pihak terkait yang menjadi narasumber di dalam penelitian ini antara lain; 1.) Prof. Dr. Adang Djumhur Salikin (Tim Pengkaji P3C), 2.) Prof. Dr. Abdussalam (Tim Pengkaji P3C), 3.) Nana Sudiana (Ketua Presidium P3C), 4.) Sultan Sepuh Ke-XIV, (P.R.A) Arief Natadiningrat, S.E. (Sultan Keraton Kasepuhan), 5.) Ratu Raja Arimbi Nurtina (Jubir Keraton Kanoman Cirebon), 6.) Sultan Abdulghani Natadiningrat (Sultan Keraton Kacirebonan), 7.) Bapak S (Anggota DPR RI), 8.) Bapak A (Anggota DPR RI). Sebagian besar narasumber mau untuk disebutkan namanya, namun terdapat dua narasumber (Anggota DPR RI) yang hanya mau disebutkan inisial namanya saja.

\section{HASIL DAN PEMBAHASAN}

\section{Un-governability Pemerintah Provinsi Jawa Barat Sebagai Faktor Determinatif Munculnya Gerakan Pemekaran Provinsi Cirebon}

Fundamen ontologis dari bermulainya gerakan pemekaran Provinsi Cirebon adalah kegagalan Provinsi Jawa Barat dalam membangun struktur kekuasaan yang adil dalam menjalankan distribusi kemakmuran sosial (ungovernability/governing failure). Di dalam proses wawancara dan observasi lapangan, peneliti menemukan kecocokan data dengan asumsi yang dibangun di dalam konstruksi teori governability yang telah dicetuskan oleh Crozier ${ }^{7}$, Watanuki ${ }^{8}$, Mayntz ${ }^{9}$, Pierre ${ }^{10}$, dan Kooiman dalam Sukardi ${ }^{11}$.

Dari bunyi teori governability yang mengatakan bahwa ada individu-individu atau aktor (oknum) pemerintah Jawa Barat yang

\footnotetext{
7 Muthiah Alagappa, Civil Society and Political Change in Asia (California: Stanford University Press, 2004), p. 63.

${ }^{8}$ Sudaryanto and dkk, Politics of Language in Indonesia (1975 - 2015) "Study of History and Language Policy (Jakarta: UNJ, 2019), p. 7.

${ }_{9}$ Mardyanto Wahyu Tryatmoko, Pemekaran Daerah Dan Persoalan Governability Di Indonesia (Jakarta: Lipi, 2016), p. 2.

${ }^{10}$ Jon dan B Guy Peters Pierre, Governing Complex Societies Trajectories and Scenarios Hampshire and New York (Palgrave: MacMillan, 2005), p. 115.

11 H Sukardi, Good Governance: Reposisi Administrasi Publik, Lensa Kapital Sosial (Malang: UMM, 2014), p. 12.
} 
"melemah" secara kapabilitas dan ada tiga syarat terpenuhinya kondisi pemerintah yang kongruen dengan tiga dimensi teori governability seperti bunyi asumsi teori di atas yang mengatakan bahwa, "penjelasan fungsi governing pemerintah akan lebih komprehensif jika dilihat dari tiga dimensi. Dimensi pertama adalah politik yang menjelaskan bagaimana penggunaan pembagian dan akuntabilitas kekuasaan. Dimensi kedua adalah legal yaitu bagaimana merumuskan dan menggunakan regulasi. Dimensi ketiga adalah manajerial yang terkait dengan pengaturan kewenangan ekstraksi sumber daya dan manajemen pembangunan. Kelemahan Pemerintah Provinsi Jabar dalam bidang penggunaan pembagian dan akuntabilitas kekuasaan, kelemahan Pemerintah Provinsi Jabar dalam ranah legal (cara merumuskan dan mengimplementasikan regulasi atau aturan) dan terakhir ketidakkapabelan Pemerintah Provinsi Jawa Barat dalam memberikan pelayanan manajerial yang terkait dengan pengaturan kewenangan dalam dimensi pengelolaan ekstraksi sumberdaya dan pembangunan.

Ketiga dimensi syarat terpenuhinya sebuah pemerintahan yang baik dalam teori governability ini semuanya gagal dilaksanakan oleh Pemerintah Provinsi Jawa Barat dikarenakan asumsi pertama teori yang mengatakan bahwa ada pelemahan secara berkala pada kapabilitas person (oknum) yang mengurus pemerintahan di Provinsi Jawa Barat.

Pada asumsi teori itu pula Kooiman ${ }^{12}$ menjelaskan perihal needs dan capacity yang pada penjelasannya, needs tidak harus berada pada rakyat atau masyarakat dan capacity tidak harus berada pada pemerintah. Keduanya merupakan satu-kesatuan dependen (saling bergantung) yang sifatnya dinamis dan bisa berada pada wilayah manapun (bisa melekat pada rakyat dan bisa pula melekat pada pemerintah). Maka dari itu Pemerintah Provinsi Jawa Barat dan masyarakat Jawa Barat harus memiliki derajat kemelekatan yang tinggi akan dua hal ini, dan keduanya (needs dan capacity) harus memiliki titik implementatif yang ekuilibrium (ada keseimbangan yang dicapai dan tidak berat sebelah). Dan pada praktiknya, rakyat Jawa Barat yang semakin tinggi derajat needs dan capacity-nya, sedangkan individu-individu yang mengurus Pemerintahan di Jawa Barat

12 Sukardi, p. 12. 
tidak berusaha untuk progresif mengejar ketertinggalan itu, maka derivatnya adalah muncul gerakan pemekaran di banyak wilayah di Jawa Barat, termasuk di Wilayah Utara Jawa Bagian Barat (Wilayah Tiga Cirebon).

Jadi alasan ontologis yang fundamental perihal mengapa terjadi pergerakan pemekaran Provinsi Cirebon, adalah karena terselenggaranya pemerintahan Provinsi Jawa Barat yang dinilai mengalami kondisi yang "un-governability" atau kurang mampu (kurang kapabel) dalam mengurus wilayah pemerintahannya sendiri. Seperti yang diungkap oleh Sultan Keraton Kasepuhan (P.R.A) Arief Natadiningrat, S.E., beliau mengatakan bahwa ;

"Jadi dulu di jaman Orde Baru itu yang banyak di bangun itu kan Bandung sentris, itu, Bandung dan sekitarnya kan. Jadi anggaran APBN, APBD ya di Bandung semua. Sayap kiri dan sayap kanan, itu Banten dan Cirebon, itu tertinggal, kenyataannya memang demikian $\operatorname{kan}^{\prime \prime}$.

\section{Para Elit Keraton Se-Cirebon, Elit Politik Indramayu dan Elit P3C Sebagai Tokoh Dominan Penggerak Pemekaran Provinsi Cirebon}

Di dalam pengupayaan gerakan pemekaran Provinsi Cirebon, pihak institusional (kelembagaan) yang paling dominatif adalah Keraton Kasepuhan dan Organisasi Presidium Pembentukan Provinsi Cirebon. Sedangkan pihak yang secara personal dominan atau paling tidak memberikan support lebih di dalam gerakan pemekaran Provinsi Cirebon adalah ${ }^{14}$ :

1. Sultan Sepuh Ke-XIV, PRA. Arief Natadiningrat, S.E. - Sultan Keraton Kasepuhan Cirebon,

2. Dr. H. Irianto M.S Syafiuddin (Yance) - Mantan Bupati Indramayu,

3. Drs. H. Dedi Supardi, M.M. - Mantan Bupati Cirebon,

4. Prof. Dr. Ir. Rokhmin Dahuri, MS. - Mantan Menteri Kelautan dan Perikanan,

\footnotetext{
${ }^{13}$ Wawancara dengan Sultan Keraton Kasepuhan, (P.R.A). Arief Natadiningrat, S.E.

${ }^{14}$ Wawancara dengan Prof. Dr. Abdussalam.
} 
5. Dan terakhir, Prof. Dr. Ir. Ginandjar Kartasasmita, M.Eng Mantan Dewan Pertimbangan Presiden RI.

6. Dai Bakhtiar (Mantan Kapolri).

Namun nama-nama tokoh di atas adalah figur-figur tokoh yang dominan men- support gerakan pemekaran Provinsi Cirebon di luar tokohtokoh internal Organisasi Presidium Pembentukan Provinsi Cirebon seperti Nana Sudiana, Prof. Dr. Adang Djumhur Salikin, Prof. Dr. Abdussalam, dan lain sebagainya.

Gerakan Yang Dilakukan Elit Keraton Se-Cirebon dan Aktivis P3C Dalam Upaya Pemekaran Provinsi Cirebon

Gerakan Pembentukan Provinsi Baru Cirebon (P3C) ini sudah melakukan beberapa upaya dalam memperjuangkan Pembentukan Provinsi Cirebon, upaya yang sudah ditempuh oleh gerakan ini adalah ${ }^{15}$ :

1. Penggalangan massa,

2. Demonstrasi atau aksi massa di beberapa tempat di Jawa Barat,

3. Konsolidasi dengan Pemerintah Kota atau Anggota Legislatif Daerah Kota Cirebon, Kabupaten Cirebon, Kabupaten Indramayu dan Kabupaten Majalengka,

4. Dialog dengan beberapa sesepuh Keraton Kasepuhan dan elit politik,

5. Pengkajian draft akademik yang di inisiasi oleh P3C yang bekerjasama dengan institusi pendidikan tinggi.

Maka penelitian ini kongruen dengan temuan data wawancara yang peneliti lakukan selama proses riset lapangan dan wawancara dengan para narasumber. Sedangkan menurut Haryanto, di dalam sebuah gerakan, pasti ada tahapan-tahapan yang harus dilewati, dan Haryanto membaginya menjadi lima tahapan yang diantaranya;

a. Tahap 1 : Pernyataan Spontan Tentang Ketidakpuasan Bersama.

b. Tahap 2 : Pemilihan Pemimpin Gerakan.

\footnotetext{
15 Idham Farsah, Inisiasi Pembentukan Provinsi Cirebon Melalui Gerakan Politik (Studi Kasus Pada Gerakan Presidium Pembentukan Provinsi Cirebon (P3C)) (Yogyakarta: UGM, 2015), p. 96.
} 
c. Tahap 3 : Transformasi tindakan yang tidak terstruktur menjadi tindakan yang terorganisir.

d. Tahap 4 : Konfrontasi dengan gerakan perlawanan .

e. Tahap 5 : Pencapaian Hasil.

Maka ketika Peneliti mencocokkan asumsi teori dengan hasil riset lapangan dan wawancara yang Peneliti lakukan, dapat Peneliti ambil kesimpulan bahwa dari lima tahapan yang diasumsikan di dalam konsep gerakan Haryanto, maka empat tahapan sudah dilakukan secara maksimal oleh aktivis P3C dan Elit Keraton Cirebon, kecuali tahapan akhir (tahap kelima), karena sampai dengan saat ini, gerakan ini mendapatkan kebuntuan seperti yang akan Peneliti bahas pada sub-bab berikutnya.

\section{Isu Propaganda Etnosentris (Sunda dan Non-Sunda/Pantura) Sebagai Alat Memperkuat Soliditas Kelompok}

Dari proses penelitian lapangan yang Peneliti lakukan, Peneliti menemukan kesimpulan bahwa, Konflik berbau etnosentris secara mikro mungkin terjadi namun konflik itu tidak terjadi di dalam masalah proses gerakan pemekaran Provinsi Cirebon, melainkan di dalam aspek sosial yang lain. Di dalam usaha gerakan pemekaran Provinsi Cirebon, isu perihal perbedaan etnis antara Sunda dan Non-Sunda (Pantura) ini lebih dijadikan alat propaganda untuk memperkuat soliditas kelompok di masing-masing pihak yang berlawanan secara politik (yang pro dan yang kontra terhadap isu pemekaran Provinsi Cirebon.)

\section{Praktik Rent-Seeking Sebagai Penyebab Substansial Kebuntuan Gerakan Pemekaran Provinsi Cirebon}

Grindle ${ }^{16}$ dengan menggunakan pendekatan ekonomi politik tahun 1970-an, "benign and walfare maximising state", menurut Grindle yang terjadi justru para pembuat kebijakan dan penyelenggara pemerintah lainnya merupakan bagian dari rent seeker (pemburu rente). Grindle dalam tulisannya (1989) dengan menggunakan pendekatan ekonomi politik tahun 1970-an, "benign and walfare maximising state", menurut Grindle yang terjadi justru para pembuat kebijakan dan penyelenggara pemerintah lainnya merupakan bagian dari rent seeker (pemburu rente)". Dan asumsi yang

${ }_{16}$ Nur Fadjrih Asyik, Political-Economy Accounting Perspective: Landasan Baru Pemberdayaan BUMN (Universitas Trunojoyo, 2010), p. 65. 
ketiga adalah, “Menurut Andi Irawan (2008), terminologi rent seeking dalam institusi negara merujuk pada perilaku pejabat publik dan politisi dalam memutuskan alokasi anggaran publik (APBN-APBD), atau kebijakan yang ditujukan untuk publik dengan motivasi mendapatkan keuntungan pribadi dan kelompok yang berimplikasi pada merugikan kepentingan publik, baik dalam jangka pendek maupun jangka panjang". Dan di dalam proses penelitian lapangan yang dilakukan oleh Peneliti, Peneliti menemukan data yang berkaitan dengan politik rente, dalam istilah yang diberikan oleh salah satu narasumber peneliti (Prof. Dr. Abdussalam) beliau memberi istilahnya, "meminta mahar". Dan hal ini terjadi tidak hanya di tingkat pusat, namun juga di tingkat daerah (kabupaten atau kota yang terkait).

Maka tepatlah apa yang sudah Grindle katakan perihal rent-seeking. Beliau mengatakan bahwa rent-seeking adalah usaha yang dilakukan untuk mengambil keuntungan dan melayani diri sendiri dari celah anggaran dan kebijakan publik. Para pejabat publik yang kemudian menjadi rent-seekers. Dan perilaku para rent-seekers yang memanfaatkan anggaran atau kebijakan publik atau wewenang menjadi kantong-kantong peruntungan yang dapat diambil secara privat (untuk pribadi atau golongannya).

\section{SIMPULAN}

Dari Penelitian yang telah selesai pengerjaannya ini, Peneliti dapat memperoleh beberapa kesimpulan yang diantaranya adalah; 1.) Ada individu-individu atau aktor (oknum) pemerintah Jawa Barat yang "melemah" secara kapabilitas. Ketiga dimensi syarat terpenuhinya sebuah pemerintahan yang baik dalam teori governability semuanya gagal dilaksanakan oleh Pemerintah Provinsi Jawa Barat dikarenakan asumsi pertama teori yang mengatakan bahwa ada pelemahan secara berkala pada kapabilitas person (oknum) yang mengurus pemerintahan di Provinsi Jawa Barat. Pemerintah Provinsi Jawa Barat dan masyarakat Jawa Barat harus memiliki derajat kemelekatan yang tinggi akan dua hal ini, dan keduanya (needs dan capacity) harus memiliki titik implementatif yang ekuilibrium (ada keseimbangan yang dicapai dan tidak berat sebelah).

Dan pada praktiknya, rakyat Jawa Barat yang semakin tinggi derajat needs dan capacity-nya, sedangkan individu-individu yang mengurus Pemerintahan di Jawa Barat tidak berusaha untuk progresif mengejar 
ketertinggalan itu, maka derivatnya adalah muncul gerakan pemekaran di banyak wilayah di Jawa Barat, termasuk di Wilayah Utara Jawa Bagian Barat (Wilayah Tiga Cirebon). Jadi alasan ontologis yang fundamental perihal mengapa terjadi pergerakan pemekaran Provinsi Cirebon, adalah karena terselenggaranya pemerintahan Provinsi Jawa Barat yang dinilai mengalami kondisi yang "un-governability" atau kurang mampu (kurang kapabel) dalam mengurus wilayah pemerintahannya sendiri. 2.) Di dalam pengupayaan gerakan pemekaran Provinsi Cirebon, pihak institusional (kelembagaan) yang paling dominatif adalah Keraton Kasepuhan dan Organisasi Presidium Pembentukan Provinsi Cirebon. Sedangkan pihak yang secara personal dominan atau paling tidak memberikan support lebih di dalam gerakan pemekaran Provinsi Cirebon adalah; 1.) Sultan Sepuh KeXIV, PRA. Arief Natadiningrat, S.E. - Sultan Keraton Kasepuhan Cirebon, 2.) Dr. H. Irianto M.S Syafiuddin (Yance) - Mantan Bupati Indramayu, 3.) Drs. H. Dedi Supardi, M.M. - Mantan Bupati Cirebon, 4.) Prof. Dr. Ir. Rokhmin Dahuri, MS. - Mantan Menteri Kelautan dan Perikanan, 5.) Dai Bakhtiar (Mantan Kapolri), 6.) Prof. Dr. Ir. Ginandjar Kartasasmita, M.Eng Mantan Dewan Pertimbangan Presiden RI, 7.) Dai Bakhtiar (Mantan Kapolri). Namun nama-nama tokoh di atas adalah figur-figur tokoh yang dominan men-support gerakan pemekaran Provinsi Cirebon di luar tokohtokoh internal Organisasi Presidium Pembentukan Provinsi Cirebon seperti Nana Sudiana, Prof. Dr. Adang Djumhur Salikin, Prof. Dr. Abdussalam, dan lain sebagainya. 3.) Gerakan yang telah diupayakan oleh Elit Keraton Se-Cirebon dan para Aktivis Organisasi Presidium Pembentukan Provinsi Cirebon (P3C) diantaranya; 1.) Konsolidasi massa, 2.) Unjuk rasa di berbagai lokasi di Provinsi Jawa Barat, 3.) Konsolidasi dengan tokoh-tokoh struktural politik (baik dari lembaga eksekutif maupun legislatif), 4.) Riset atau Kajian kelayakan Wilayah Tiga Cirebon untuk dapat berdiri otonom sebagai sebuah provinsi baru, 5.) Hearing dan seminar ilmiah (temu pendapat) dengan berbagai kalangan (tokoh masyarakat, ulama, akademisi, politisi, serta para pengusaha atau pemodal). 4.) Konflik berbau etnosentris secara mikro mungkin terjadi namun konflik itu tidak terjadi di dalam masalah proses gerakan pemekaran Provinsi Cirebon, melainkan di dalam aspek sosial yang lain.

Di dalam usaha gerakan pemekaran Provinsi Cirebon, isu perihal perbedaan etnis antara Sunda dan Non-Sunda (Pantura) ini lebih dijadikan 
alat propaganda untuk memperkuat soliditas kelompok di masing-masing pihak yang berlawanan secara politik (yg pro dan yang kontra terhadap isu pemekaran Provinsi Cirebon). Alasan substansial sebenarnya dari kebuntuan gerakan pemekaran Provinsi Cirebon adalah bukan karena alasan perbedaan atau konflik antar etnis, sebab yang sebenarnya adalah karena kurangnya modal kapital para aktivis penggerak usaha pemekaran Provinsi Cirebon. Modal kapital seperti yang sudah Prof. Dr. Abdussalam katakan, adalah salah satu dari tiga kekuatan besar bagi daerah yang ingin melakukan pemekaran (selain dari pada kekuatan intervensi sosial dan kekuatan struktur politik). Dan tepatlah apa yang sudah Grindle katakan perihal rent-seeking. Beliau mengatakan bahwa rent-seeking adalah usaha yang dilakukan untuk mengambil keuntungan dan melayani diri sendiri dari celah anggaran dan kebijakan publik. Para pejabat publik yang kemudian menjadi rent-seekers. Dan perilaku para rent-seekers yang memanfaatkan anggaran atau kebijakan publik atau wewenang menjadi kantong-kantong peruntungan yang dapat diambil secara privat (untuk pribadi atau golongannya). 


\section{DAFTAR PUSTAKA}

Alagappa, Muthiah, Civil Society and Political Change in Asia (California: Stanford University Press, 2004)

Asyik, Nur Fadjrih, Political-Economy Accounting Perspective: Landasan Baru Pemberdayaan BUMN (Universitas Trunojoyo, 2010)

Banten, Humas Protokol, 'Profil Provinsi Banten' $<$ http://www.humasprotokol.bantenprov.go.id/2012/07/profil-provinsibanten/> [accessed 9 December 2018]

Cirebon, Radar, 'Gerakan Pemekaran Provinsi Cirebon Diabaikan', 2018 $<$ http://radarcirebon.com/2010/09/berita-nasional/provinsi-cirebondiabaikan/> [accessed 7 December 2018]

Farsah, Idham, Inisiasi Pembentukan Provinsi Cirebon Melalui Gerakan Politik (Studi Kasus Pada Gerakan Presidium Pembentukan Provinsi Cirebon (P3C)) (Yogyakarta: UGM, 2015)

Hanif, Hasrul, and Pratikno, Perjuangan Menuju Puncak (Yogyakarta: Program Pascasarjana (S2) Politik Lokal dan Otonomi Daerah UGM, 2006)

Pierre, Jon dan B Guy Peters, Governing Complex Societies Trajectories and Scenarios Hampshire and New York (Palgrave: MacMillan, 2005)

Ratnawati, Tri, Potret Pemerintahan Lokal Di Indonesia Di Masa Perubahan (Jakarta: Pustaka Pelajar, 2006)

Simandjuntak, Reynold, Sistem Desentralisasi Dalam Negara Kesatuan Republik Indonesia Perspektif Yuridis Konstitusional (Manado: UGM, 2015)

Sudaryanto, and dkk, Politics of Language in Indonesia (1975 - 2015) "Study of History and Language Policy (Jakarta: UNJ, 2019)

Sukardi, H, Good Governance: Reposisi Administrasi Publik, Lensa Kapital Sosial (Malang: UMM, 2014)

Tryatmoko, Mardyanto Wahyu, Pemekaran Daerah Dan Persoalan Governability Di Indonesia (Jakarta: Lipi, 2016) 
Wawancara dengan Sultan Keraton Kasepuhan, (P.R.A). Arief Natadiningrat, S.E.

Wawancara dengan Prof. Dr. Abdussalam. 